\title{
ROLES OF ALLOYING ELEMENTS ON THE CORROSION BEHAVIOR OF SPUTTER-DEPOSITED AMORPHOUS W-Cr-Zr ALLOYS IN $0.5 \mathrm{M}$ NaCl SOLUTION
}

\author{
Jagadeesh Bhattarai \\ Central Department of Chemistry, Tribhuvan University, Kirtipur, Kathmandu, Nepal.
}

\begin{abstract}
Ternary amorphous W-xCr-yZr alloys containing 9-38 at \% tungsten, 15-42 at \% chromium and 39-73 at \% zirconium were successfully prepared by direct current (DC) magnetron sputtering technique. The corrosion rates of all the examined sputter-deposited W-xCr-yZr alloys were in the range of $1 \times 10^{-3} \mathrm{~mm} / \mathrm{y}$ or lower which are nearly one order of magnitude lower than those of the sputter-deposited tungsten, chromium and zirconium metals after immersion for $240 \mathrm{~h}$ in $0.5 \mathrm{M} \mathrm{NaCl}$ solution open to air at $25^{\circ} \mathrm{C}$. In particular, the simultaneous additions of tungsten, chromium and zirconium to the amorphous ternary W-xCr-yZr alloys in the chromium- and zirconium-enriched W-91Cr and W-88Zr alloys, respectively, showed a synergistic effects for showing the higher corrosion resistance than those of binary WCr and W-Zr alloys in neutral $\mathrm{NaCl}$ solution.
\end{abstract}

Keywords: W-Cr-Zr alloys; Sputter deposition; Corrosion test; Open circuit potential; $0.5 \mathrm{M} \mathrm{NaCl.}$

\section{INTRODUCTION}

The use of the sputter deposition technique is becoming a quite suitable method for tailoring of corrosion-resistant amorphous alloys for last two decades. Even if amorphous alloy is not formed by the sputter deposition technique, the alloys thus prepared are always composed of nanocrystals with very fine grains and sometimes behaves similar to the single-phase amorphous or/and nanocrystalline alloys. The chemically homogeneous single-phase nature of amorphous or/and nanocrystalline alloys is generally responsible for their high corrosion resistance owing to the formation of uniform protective passive films those are able to separate bulk of alloys from aggressive environments. From the corrosion point of view, they can be considered as homogeneous alloys. Accordingly, the sputter-deposited alloys consisting of either amorphous and nanocrystalline single-phase solid solutions are chemically homogeneous and hence are interesting in the view of corrosion resistance properties.

Tungsten, chromium and zirconium are regarded as very effective alloying elements for enhancing the corrosion resistance of alloys in aggressive environments. It has been reported that the sputter-deposited amorphous or/and nanocrystalline tungsten-based binary $\mathrm{W}-\mathrm{Ti}^{1-5}, \mathrm{~W}-\mathrm{Zr}^{2,6,7}$, $\mathrm{W}-\mathrm{Ni}^{8,9}, \mathrm{~W}-\mathrm{Cr}^{2,7,10-13}, \mathrm{~W}-\mathrm{Nb}^{2,7,14-16}, \mathrm{~W}-\mathrm{Ta}^{2,7,17}, \mathrm{~W}-\mathrm{Mo}^{8,18}$ and ternary $\mathrm{W}-\mathrm{Cr}-\mathrm{Ni}^{19,20}$ as well as $\mathrm{Cr}-\mathrm{Zr}-\mathrm{W}^{21}$ alloys were spontaneously passivated showing significantly higher corrosion resistance than those of alloy-constituting elements in $12 \mathrm{M} \mathrm{HCl}$ solution. The significant improvement of the corrosion resistance properties of the amorphous or/ and nanocrystalline alloys was attributed to the formation of double or triple oxyhydroxide passive films containing both tungsten and alloy-constituting cations which are more resistance and stable for both uniform and localized corrosion in comparison with the oxyhydroxides of tungsten and other alloy-constituting elements. It has been reported that the corrosion resistance of the sputter-deposited amorphous or/and nanocrystalline W-Zr alloys were passivated spontaneously and observed significantly high corrosion resistance in aggressive environments ${ }^{2,6,7}$. The corrosionresistant of the sputter-deposited $\mathrm{W}-\mathrm{Zr}$ alloys has been reported higher than those of tungsten and zirconium in 12 $\mathrm{M} \mathrm{HCl}^{2,6,7}, 0.5 \mathrm{M} \mathrm{NaCl}^{22}$ and $1 \mathrm{M} \mathrm{NaOH}^{22}$ solutions.

On the other hand, chromium is one of the most effective alloying elements to provide a high passivating ability for conventional steels and stainless steels. Only a small amount of chromium (8 at \%) addition was enough to cause spontaneous passivation of steels in $1 \mathrm{M} \mathrm{HCl}$ and they showed significantly higher pitting corrosion resistance than stainless steels ${ }^{23,24}$. A series of the sputter-deposited chromium-metalloid alloys exhibited superior corrosion resistance compared to chromium metal in $12 \mathrm{M} \mathrm{HCl}^{25}$. It has been reported that only small amount of tungsten addition (that is, about 9 at \%) was enough to cause spontaneous passivation of the sputter-deposited nanocrystalline $\mathrm{W}-\mathrm{Cr}$ alloys even in $12 \mathrm{M} \mathrm{HCl}$ and these alloys showed about five orders of magnitude lower corrosion rate than the corrosion rate of chromium metal, and about one order of magnitude lower corrosion rate than that of tungsten ${ }^{10-13}$. In recent years, the sputter-deposited nanocrystalline $\mathrm{W}-\mathrm{Cr}$ alloys containing 25-75 at\% chromium showed nearly two orders 
of magnitude lower than that of tungsten and more than one order of magnitude lower corrosion rate than that of sputterdeposited chromium in $1 \mathrm{M} \mathrm{NaOH}$ solution ${ }^{26}$. Similarly, the sputter-deposited W-(25-91)Cr alloys showed about one order of magnitude lower corrosion rates than those of tungsten and chromium metals in $0.5 \mathrm{M} \mathrm{NaCl}$ solution at $25^{\circ} \mathrm{C}^{26}$.

Zirconium is one of the corrosion-resistant elements in acidic environments, although it suffers pitting corrosion by anodic polarization in chloride containing solutions. The alloying of zirconium with aluminum ${ }^{27}$, chromium ${ }^{28}$ and molybdenum ${ }^{29}$ greatly improved the corrosion resistance of the alloys in acidic solutions. Chromium and tungsten are known to be effective elements in improving the pitting corrosion resistance of the alloys, whereas zirconium suffers pitting corrosion by anodic polarization in aggressive chloridecontaining environments. The immunity to pitting corrosion is one of the most interesting characteristics of alloys. It has been reported that the synergistic improvement in the resistance to passivity breakdown in chloride-containing media was observed when chromium and zirconium were added simultaneously to the sputter-deposited $\mathrm{Mn}-\mathrm{Zr}-\mathrm{Cr}$ alloys instead of single addition of zirconium or chromium metals ${ }^{30}$. It has been recently reported that the simultaneous additions of 10 at $\%$ tungsten in presence of $15-17$ at $\%$ chromium in the sputter-deposited amorphous or nanocrystalline $\mathrm{Cr}-\mathrm{Zr}-\mathrm{W}$ alloys enhanced significantly the pitting corrosion as well as uniform corrosion of the zirconium metal in $12 \mathrm{M} \mathrm{HCl}$ solution open to air at $30^{\circ} \mathrm{C}^{21}$. It is noteworthy for mentioning here that both zirconium ${ }^{31}$ and chromium $^{32}$ metals are very corrodible in acidic or very alkaline $(>13 \mathrm{pH})$ solutions. However, both zirconium and chromium metals do not corrode in neutral $0.5 \mathrm{M} \mathrm{NaCl}$ solution, mostly due to the formation of zirconium oxides ${ }^{31}$ and chromium hydroxide/oxides ${ }^{32}$, respectively. On the other hand, tungsten metal corrodes in solution having $\mathrm{pH} 4$ or high ${ }^{33}$, for example, in $0.5 \mathrm{M} \mathrm{NaCl}$ solution. Accordingly, it might be expected that effects of tungsten, chromium and zirconium additions enhance in the corrosion resistance of the sputter-deposited amorphous or nanocrystalline $\mathrm{W}-\mathrm{Cr}-\mathrm{Zr}$ alloys in $\mathrm{NaCl}$ solution.

In this context, the main objective of the present work is aimed to clarify the effects of simultaneous additions of tungsten, chromium and zirconium metal on the corrosion behavior of the sputter-deposited ternary $\mathrm{W}-\mathrm{xCr}-\mathrm{yZr}$ alloys in $0.5 \mathrm{M} \mathrm{NaCl}$ solution open to air at $25^{\circ} \mathrm{C}$ using corrosion tests and open circuit potential measurements.

\section{MATERIALS AND METHODS}

The sputter-deposited ternary $\mathrm{W}-\mathrm{xCr}-\mathrm{yZr}$ alloys containing 9-38 at\% tungsten, 15-42 at\% chromium and 39-73 at\% zirconium were characterized as single-phase solid solution of amorphous structure having apparent grain size ranging 0.9 to $1.4 \mathrm{~nm}$ using X-ray diffraction (XRD) patterns (Table 1$)^{21}$. The compositions of the sputter-deposited $\mathrm{W}-\mathrm{Cr}-\mathrm{Zr}$ alloys were determined using electron probe microanalysis (EPMA) and hereafter are all denoted in atomic percentage (at\%).
Table 1: Composition, structure and apparent grain size of the sputterdeposited ternary $\mathrm{W}-\mathrm{Cr}-\mathrm{Zr}$ alloys including sputter-deposited tungsten, chromium and zirconium ${ }^{21}$.

\begin{tabular}{|l|l|c|}
\hline \multicolumn{1}{|c|}{ Name of Alloy } & Structure & Apparent Grain Size (nm) \\
\hline Sputtered Tungsten & nanocrystalline & 20.0 \\
\hline $9 \mathrm{~W}-33 \mathrm{Cr}-58 \mathrm{Zr}$ & amorphous & 1.0 \\
\hline $10 \mathrm{~W}-17 \mathrm{Cr}-73 \mathrm{Zr}$ & amorphous & 1.4 \\
\hline $19 \mathrm{~W}-42 \mathrm{Cr}-39 \mathrm{Zr}$ & amorphous & 0.9 \\
\hline $20 \mathrm{~W}-30 \mathrm{Cr}-50 \mathrm{Zr}$ & amorphous & 1.0 \\
\hline $21 \mathrm{~W}-15 \mathrm{Cr}-64 \mathrm{Zr}$ & amorphous & 1.2 \\
\hline $31 \mathrm{~W}-15 \mathrm{Cr}-54 \mathrm{Zr}$ & amorphous & 1.1 \\
\hline $38 \mathrm{~W}-21 \mathrm{Cr}-41 \mathrm{Zr}$ & amorphous & 1.0 \\
\hline Sputtered Chromium & nanocrystalline & 40.0 \\
\hline Sputtered Zirconium & nanocrystalline & 24.0 \\
\hline
\end{tabular}

Prior to the corrosion tests and electrochemical measurements, the sputter-deposited $\mathrm{W}-\mathrm{Cr}-\mathrm{Zr}$ alloy specimens were mechanically polished with a silicon carbide paper up to grit number 1500 in cyclohexane, degreased by acetone and dried in air. The average corrosion rate of the alloys was estimated from the weight loss after immersion for $240 \mathrm{~h}$ in $0.5 \mathrm{M} \mathrm{NaCl}$ solution open to air at $25^{\circ} \mathrm{C}$. The corrosion rate measurement by weight loss method was carried out 23 times so as to get the average corrosion rate of the alloys. The time dependence of the corrosion rate of the $\mathrm{Zr}-(12-$ 21)Cr-W alloys was also estimated at various time intervals. The corrosion rate of the individual alloy was estimated by using equation (1) as given below $w^{2,8,34}$ :

Corrosion Rate $\left(\mathrm{mm}^{-1} \mathrm{y}^{-1}\right)=\frac{\Delta \mathrm{w} \times 8760 \times 10}{\mathrm{~d} \times \mathrm{A} \times \mathrm{t}}$

where, Äw is weight loss of the alloy specimen in grams; $d$ is density of the alloy specimen in $\mathrm{g} / \mathrm{cm}^{3}$; A is area of the alloy specimen in $\mathrm{cm}^{2}$, and; $\mathrm{t}$ is time of immersion in hour.

The open circuit potential of the sputter-deposited ternary W-Cr-Zr alloys was measured after immersion for 72 hours in $0.5 \mathrm{M} \mathrm{NaCl}$ solution open to air at $25^{\circ} \mathrm{C}$. All the electrochemical measurements were performed 2-3 times. A platinum mesh and saturated calomel electrode were used as counter and reference electrodes, respectively. All the potentials given in this paper are relative to saturated calomel electrode (SCE).

\section{RESULTS AND DISCUSSION}

Figure 1 shows the corrosion rates of the sputter-deposited binary $\mathrm{W}-\mathrm{Cr}$ and $\mathrm{W}-\mathrm{Zr}$ alloys in $0.5 \mathrm{M} \mathrm{NaCl}$ solution. The corrosion rates of the nanocrystalline $\mathrm{W}-\mathrm{Cr}$ alloys containing about 25-91 at\% chromium showed about one order of magnitude lower corrosion rates than those of the sputterdeposited tungsten and chromium metals in $0.5 \mathrm{M} \mathrm{NaCl}$ solutions after immersion for $240 \mathrm{~h}$ at $25^{\circ} \mathrm{C}$. Similarly, the sputter-deposited amorphous W-Zr alloys containing 2376 at $\%$ zirconium showed lower corrosion rates than those of alloy-constituting elements (that is, tungsten and zirconium) in $0.5 \mathrm{M} \mathrm{NaCl}$ solution at $25^{\circ} \mathrm{C}$. However, the corrosion rate of the $\mathrm{W}-88 \mathrm{Zr}$ alloy is almost same as that of the sputterdeposited zirconium metal. These results revealed that the synergistic effect of the chromium and zirconium additions to the W-Cr and WZr alloys, respectively, is clearly observed 
in $0.5 \mathrm{M} \mathrm{NaCl}$ solution open to air at $25^{\circ} \mathrm{C}$. Furthermore, it is cleared form the results that both of the sputter-deposited $\mathrm{W}-\mathrm{Cr}$ and $\mathrm{W}-\mathrm{Zr}$ alloys showed almost same corrosion rates in $0.5 \mathrm{M} \mathrm{NaCl}$ solution. In this context, it is very interesting to study the simultaneous additions of tungsten, chromium and zirconium metals to enhance the corrosion resistance property of the ternary $\mathrm{W}-\mathrm{Cr}-\mathrm{Zr}$ alloys in $0.5 \mathrm{M} \mathrm{NaCl}$ solution.

In particular, the role of the simultaneous additions of the three alloy-constituting elements (that is, tungsten, chromium and zirconium) on the corrosion behavior of the binary chromium- and zirconium-enriched $\mathrm{W}-\mathrm{Cr}$ and $\mathrm{W}-\mathrm{Zr}$ alloys, respectively, is focused in this study. Figure 2 shows the corrosion rates of two ternary $\mathrm{W}-\mathrm{xCr}-\mathrm{yZr}$ alloys, that is, $31 \mathrm{~W}-15 \mathrm{Cr}-54 \mathrm{Zr}$ and $38 \mathrm{~W}-21 \mathrm{Cr}-41 \mathrm{Zr}$ alloys in $0.5 \mathrm{M} \mathrm{NaCl}$ solution at $25^{\circ} \mathrm{C}$. The corrosion rates of the binary $43 \mathrm{~W}-$ $57 \mathrm{Cr}$ and $46 \mathrm{~W}-54 \mathrm{Zr}$ alloys are also shown for comparison. The corrosion rates of the ternary $\mathrm{W}-\mathrm{xCr}-\mathrm{yZr}$ alloys are almost same as those of the binary 43W-57Cr and 46W-54Zr alloys in $0.5 \mathrm{M} \mathrm{NaCl}$ at $25^{\circ} \mathrm{C}$. These results revealed that the corrosion resistance property of these two ternary alloys is not significantly improved with the simultaneous additions of tungsten, chromium and zirconium in the binary $\mathrm{W}-\mathrm{Cr}$ and W-Zr alloys containing 43-46 at\% tungsten.

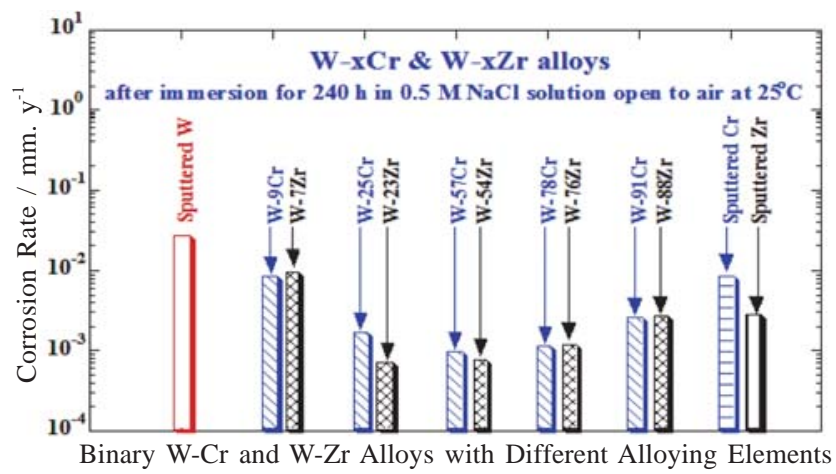

Figure 1: Corrosion rates of the sputter-deposited nanocrystalline W$\mathrm{Cr}$ and amorphous $\mathrm{W}-\mathrm{Zr}$ alloys after immersion for $240 \mathrm{~h}$ in $0.5 \mathrm{M} \mathrm{NaCl}$ solution open to air at $25^{\circ} \mathrm{C}$. Corrosion rates of the sputter-deposited tungsten, chromium and zirconium are also shown for comparison.

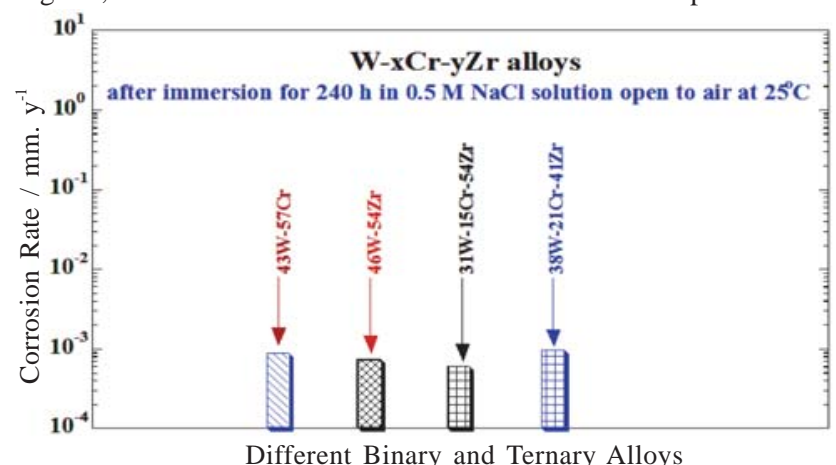

Figure 2: Corrosion rates of amorphous ternary $\mathrm{W}-15 \mathrm{Cr}-54 \mathrm{Zr}$ and $\mathrm{W}-21 \mathrm{Cr}-41 \mathrm{Zr}$ alloys after immersion for $240 \mathrm{~h}$ in $0.5 \mathrm{M} \mathrm{NaCl}$ solution open to air at $25^{\circ} \mathrm{C}$. Corrosion rates of the binary $\mathrm{W}-57 \mathrm{Cr}$ and $\mathrm{W}-$ $54 \mathrm{Zr}$ alloys are also shown for comparison.

Similarly, the role of the simultaneous additions of tungsten, chromium and zirconium on the corrosion behavior of the sputter-deposited binary 22W-78Cr and 24W-76Zr alloys in $0.5 \mathrm{M} \mathrm{NaCl}$ was studied. Figure 3 shows the corrosion rates of three ternary $\mathrm{W}-\mathrm{Cr}-\mathrm{Zr}$ alloys, that is, $21 \mathrm{~W}-15 \mathrm{Cr}-$ 64Zr, 20W-30Cr-50Zr and 19W-42Cr-39Zr alloys after immersion for $240 \mathrm{~h}$ in $0.5 \mathrm{M} \mathrm{NaCl}$ solution open to air at $25^{\circ} \mathrm{C}$. The corrosion rates of the binary $22 \mathrm{~W}-78 \mathrm{Cr}$ and $24 \mathrm{~W}-$ $76 Z r$ alloys are also shown for comparison. The corrosion rates of these three ternary $\mathrm{W}-\mathrm{xCr}-\mathrm{yZr}$ alloys containing different amounts of chromium and zirconium, in which the amount of tungsten is kept almost same (that is, about 20 at $\%$ ), are almost same as those of the binary $22 \mathrm{~W}-78 \mathrm{Cr}$ and $24 \mathrm{~W}-76 \mathrm{Zr}$ alloys in $0.5 \mathrm{M} \mathrm{NaCl}$ at $25^{\circ} \mathrm{C}$. These results revealed that the corrosion resistance property of these three ternary $\mathrm{W}-\mathrm{xCr}-\mathrm{yZr}$ alloys is not significantly improved with the simultaneous additions of tungsten, chromium and zirconium in the binary $\mathrm{W}-\mathrm{Cr}$ and $\mathrm{WZr}$ alloys containing 43-46 at\% tungsten. However, the corrosion rate of the ternary $21 \mathrm{~W}-$ 15Cr-64Zr alloy is slightly lower than those of other two $21 \mathrm{~W}-15 \mathrm{Cr}-64 \mathrm{Zr}$ and $21 \mathrm{~W}-15 \mathrm{Cr}-64 \mathrm{Zr}$ alloys. This is mostly due to the lower corrosion rate of the pure sputter-deposited zirconium than that of chromium metal as shown in Fig.1, because the $21 \mathrm{~W}-15 \mathrm{Cr}-64 \mathrm{Zr}$ alloy contains higher amounts of zirconium than those other two ternary alloys.

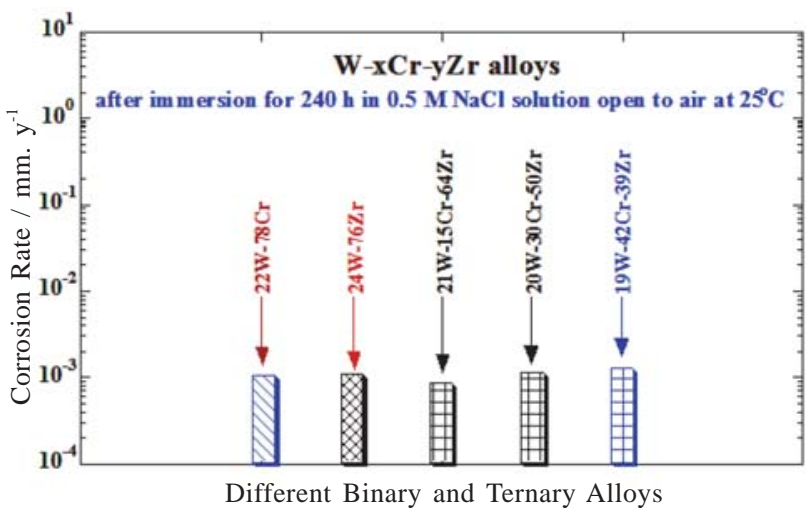

Figure 3: Corrosion rates of the sputter-deposited amorphous W15Cr-64Zr, W-30Cr-50Zr and W-42Cr-39Zr alloys after immersion for $240 \mathrm{~h}$ in $0.5 \mathrm{M} \mathrm{NaCl}$ solution open to air at $25^{\circ} \mathrm{C}$. Corrosion rates of the binary W-78Cr and W-76Zr alloys are also shown for comparison.

Figure 4 shows the effects of the simultaneous additions of tungsten, chromium and zirconium metals on the corrosion behavior of the sputter-deposited binary 9W-91Cr and 12W$88 \mathrm{Zr}$ alloys in $0.5 \mathrm{M} \mathrm{NaCl}$ solution after immersion for $240 \mathrm{~h}$ at $25^{\circ} \mathrm{C}$. The corrosion rates of the binary $9 \mathrm{~W}-91 \mathrm{Cr}$ and $12 \mathrm{~W}-$ 88Zr alloys are also shown for comparison. The corrosion rates of sputter-deposited ternary 9W-33Cr-58Zr and 10W17Cr-73Zr alloys after immersion for $240 \mathrm{~h}$ in $0.5 \mathrm{M} \mathrm{NaCl}$ solution open to air at $25^{\circ} \mathrm{C}$ are clearly lower than those of the binary $9 \mathrm{~W}-91 \mathrm{Cr}$ and $12 \mathrm{~W}-88 \mathrm{Zr}$ alloys. These results revealed that the corrosion resistance property of the binary chromium- and zirconium-enriched W-91Cr and W-88Zr containing 9-12 at\% tungsten is synergistically improved by simultaneous additions of tungsten, chromium and zirconium in $0.5 \mathrm{M} \mathrm{NaCl}$. Consequently, it can be concluded that the simultaneous additions of tungsten, chromium and zirconium in the chromium- or/and zirconium-enriched binary $\mathrm{W}-91 \mathrm{Cr}$ and $\mathrm{W}-88 \mathrm{Zr}$ is effective to improve the corrosion 
resistance property of the sputter-deposited ternary $\mathrm{W}-\mathrm{xCr}-$ yZr alloys in neutral $\mathrm{NaCl}$ solutions at $25^{\circ} \mathrm{C}$. In this context, it will be very interesting to study the pitting corrosion of these ternary chromium- or/and zirconium-enriched $\mathrm{W}-\mathrm{xCr}-\mathrm{yZr}$ alloys in $\mathrm{NaCl}$ solutions which is not the aims of the present study.

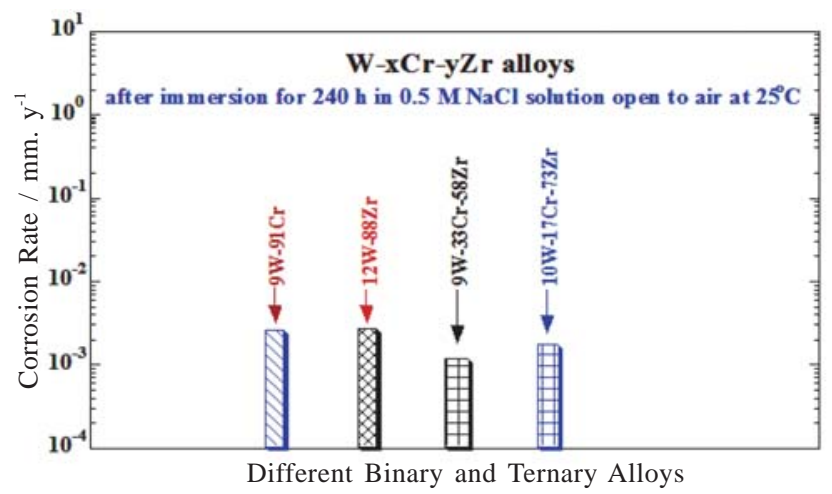

Figure 4: Corrosion rates of the sputter-deposited amorphous W33Cr-58Zr and W-17Cr-73Zr alloys after immersion for $240 \mathrm{~h}$ in $0.5 \mathrm{M} \mathrm{NaCl}$ solution open to air at $25^{\circ} \mathrm{C}$. Corrosion rates of the binary W-91Cr and W-88Zr alloys are also shown for comparison.

Open circuit potential measurement was carried out for a better understanding of the roles of the simultaneous additions of tungsten, chromium and zirconium in the sputter-deposited ternary $\mathrm{W}-\mathrm{xCr}-\mathrm{yZ}$ r alloys for their corrosion behavior study in $0.5 \mathrm{M} \mathrm{NaCl}$ solution. Figure 5 shows the open circuit potential of the sputter-deposited binary $\mathrm{W}-\mathrm{xCr}$ and $\mathrm{W}-$ yZr alloys including tungsten, chromium and zirconium metals after immersion for $72 \mathrm{~h}$ in $0.5 \mathrm{M} \mathrm{NaCl}$ solution open to air at $25^{\circ} \mathrm{C}$. The open circuit potentials of all the examined nanocrystalline $\mathrm{W}-\mathrm{Cr}$ and amorphous $\mathrm{W}-\mathrm{Zr}$ alloys show almost same value between 0 to $-60 \mathrm{mV}$ (SCE) after immersion for $72 \mathrm{~h}$ in $0.5 \mathrm{M} \mathrm{NaCl}$ except the tungsten metal and $\mathrm{W}-9 \mathrm{Cr}$ alloy. The open circuit potentials of the sputter-deposited tungsten and W-9Cr alloy were found -654 and $-446 \mathrm{mV}$ (SCE), respectively. It is meaningful to mention here that why $72 \mathrm{~h}$ is selected to record the open circuit potentials of all the examined binary and ternary alloys in this study. Because it was found that the changes of corrosion rates of these binary and ternary alloys including tungsten, chromium and zirconium metals were observed a steady state corrosion values with immersion time after immersion for 48 to $240 \mathrm{~h}$ in $0.5 \mathrm{M} \mathrm{NaCl}$ solution (not presented the data here).

Similarly, Figs 6, 7 and 8 show the changes in the open circuit potentials of the sputter-deposited ternary $\mathrm{W}-\mathrm{xCr}-\mathrm{yZ}$ r alloys after immersion for $72 \mathrm{~h}$ in $0.5 \mathrm{M} \mathrm{NaCl}$ solution open to air at $25^{\circ} \mathrm{C}$. The open circuit potentials of the sputter-deposited chromium- and zirconium-enriched $\mathrm{W}-\mathrm{xCr}$ and $\mathrm{W}-\mathrm{yZr}$ alloys after immersion for $72 \mathrm{~h}$ in $0.5 \mathrm{M} \mathrm{NaCl}$ are also shown for comparison. The open circuit potentials of all examined sputter-deposited amorphous $\mathrm{W}-\mathrm{xCr}-\mathrm{yZr}$ alloys are almost same as those of the sputter-deposited chromium- and zirconium-enriched binary $\mathrm{W}-\mathrm{Cr}$ and $\mathrm{W}-\mathrm{Zr}$ alloys and are reached a steady state values between 0 to $-60 \mathrm{mV}$ (SCE) after immersion for $72 \mathrm{~h}$ in $0.5 \mathrm{M} \mathrm{NaCl}$. This result of showing the almost same open circuit potential values of all examined

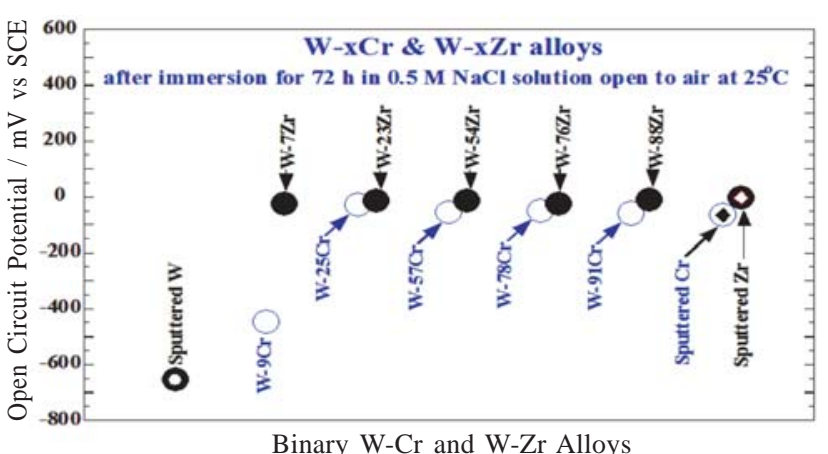

Figure 5: Open circuit potentials of the sputter-deposited nanocrystalline $\mathrm{W}-\mathrm{Cr}$ and amorphous $\mathrm{W}-\mathrm{Zr}$ alloys after immersion for $72 \mathrm{~h}$ in $0.5 \mathrm{M} \mathrm{NaCl}$ solution open to air at $25^{\circ} \mathrm{C}$. Open circuit potentials of the sputterdeposited tungsten, chromium and zirconium are also shown for comparison.

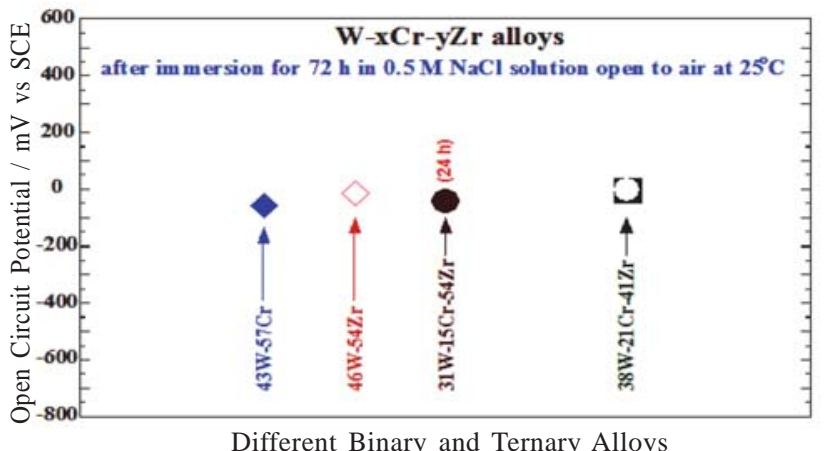

Figure 6: Open circuit potentials of amorphous ternary $\mathrm{W}-15 \mathrm{Cr}-$ $54 \mathrm{Zr}$ and $\mathrm{W}-21 \mathrm{Cr}-41 \mathrm{Zr}$ alloys after immersion for $72 \mathrm{~h}$ in $0.5 \mathrm{M}$ $\mathrm{NaCl}$ solution open to air at $25^{\circ} \mathrm{C}$. Open circuit potentials of the binary $\mathrm{W}-57 \mathrm{Cr}$ and $\mathrm{W}-54 \mathrm{Zr}$ alloys are also shown for comparison.

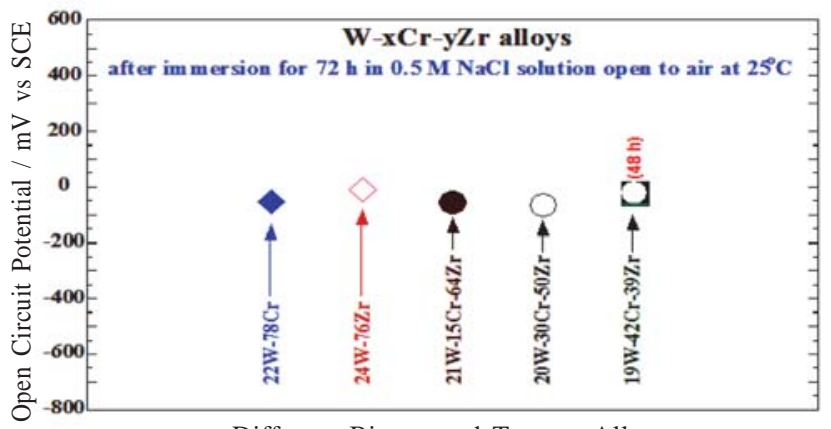

Different Binary and Ternary Alloys

Figure 7: Open circuit potentials of the sputter-deposited amorphous W15Cr-64Zr, W-30Cr-50Zr and W-42Cr-39Zr alloys after immersion for $72 \mathrm{~h}$ in $0.5 \mathrm{M} \mathrm{NaCl}$ solution open to air at $25^{\circ} \mathrm{C}$. Open circuit potentials of the binary $\mathrm{W}-78 \mathrm{Cr}$ and $\mathrm{W}-76 \mathrm{Zr}$ alloys are also shown for comparison.

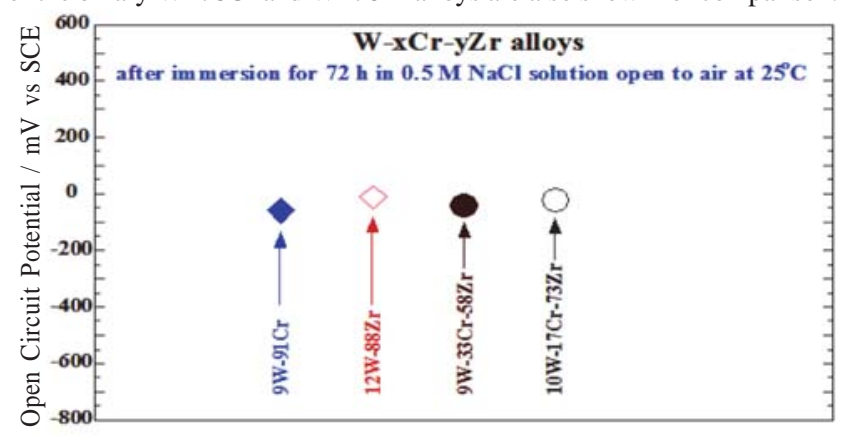

Different Binary and Ternary Alloys

Figure 8: Open circuit potentials of amorphous ternary $\mathrm{W}-33 \mathrm{Cr}-$ $58 \mathrm{Zr}$ and $\mathrm{W}-17 \mathrm{Cr}-73 \mathrm{Zr}$ alloys after immersion for $72 \mathrm{~h}$ in $0.5 \mathrm{M}$ $\mathrm{NaCl}$ solution open to air at $25^{\circ} \mathrm{C}$. Open circuit potentials of the binary W-91Cr and W-88Zr alloys are also shown for comparison. 
ternary $\mathrm{W}-\mathrm{xCr}-\mathrm{yZr}$ alloys in $0.5 \mathrm{M} \mathrm{NaCl}$ after immersion for $72 \mathrm{~h}$ is in agreement with showing the almost same corrosion rates of all these alloys in $0.5 \mathrm{M} \mathrm{NaCl}$ solutions as shown in Figs 1-4.

\section{CONCLUSIONS}

The simultaneous additions of tungsten, chromium and zirconium in the chromium- and zirconium-enriched binary $\mathrm{W}-\mathrm{Cr}$ and $\mathrm{W}-\mathrm{Zr}$ is effective to improve the corrosion resistance property of the sputter-deposited ternary $\mathrm{W}-\mathrm{xCr}-$ yZr alloys after immersion for $240 \mathrm{~h}$ in $0.5 \mathrm{M} \mathrm{NaCl}$ solution open to air at $25^{\circ} \mathrm{C}$. On the other hand, the simultaneous additions of tungsten, chromium and zirconium in the sputterdeposited $\mathrm{W}-\mathrm{xCr}-\mathrm{yZr}$ alloys is not effective to shift the open circuit potential of these alloys to more noble directions than those of the open circuit potential values of the chromiumor/and zirconium-enriched binary $\mathrm{W}-\mathrm{Cr}$ and $\mathrm{W}-\mathrm{Zr}$ alloys in $0.5 \mathrm{M} \mathrm{NaCl}$ solution.

\section{REFERENCES}

1. Bhattarai, J., Akiyama, E., Kawashima, A., Asami K. and Hashimoto, K. 1995. Corrosion Science. 37: 2071-2086.

2. Bhattarai, J .1998. Tailoring of Corrosion-Resistant Tungsten Alloys by Sputtering, Doctoral Thesis, Department of Materials Science, Faculty of Engineering, Tohoku University, Japan. pp. 229.

3. Hashimoto, K., Bhattarai, J., Li, X. Y., Park, P. Y., Kim, J. H., Akiyama, E., Habazaki, H., Kawashima, A., Asami K. and Shimamura, K. 1998. Proc. of the Special Symposium on Passivity and its Breakdown (eds P. M. Natishan, H. S. Isaacs, M. Janik-Czachor, V. A. Macagno, P. Marcus and M. Seo). The Electrochemical Society Inc., Pennington, USA, pp. 369-383.

4. Bhattarai, J. 2000. Journal of Nepal Chemical Society. 19: 32-42.

5. Bhattarai, J. 2002. Nepal Journal of Science and Technology. 4: 37-43.

6. Bhattarai, J., Akiyama, E., Habazaki, H., Kawashima, A., Asami K. and Hashimoto, K. 1997. Corrosion Science. 39: 353-375.

7. Bhattarai, J., Kawashima, A., Asami K. and Hashimoto, K. 1999. Proc. $3^{\text {rd }}$ National Conference on Science and Technology, Kathmandu, Nepal. vol. 1: 389-407.

8. Bhattarai, J. 1995. The Corrosion Behavior of Sputter-deposited Tungsten-base Alloys. Research Reports, Institute for Materials Research (IMR), Tohoku University, Sendai, Japan. pp. 43+IV.

9. Bhattarai, J. 2001. Journal of Nepal Chemical Society. 20: 24-40.

10. Bhattarai, J., Akiyama, E., Habazaki, H., Kawashima, A., Asami K. and Hashimoto, K. 1998. Corrosion Science. 40: 155-175.

11. Bhattarai, J. and Hashimoto, K. 1998. Tribhuvan University Journal. 21(2): 1-16.

12. Bhattarai, J. 2000. Journal of Nepal Chemical Society. 19: 1-14.
13. Bhattarai, J. 2002. Journal of Institute of Science and Technology. 12: 125-138.

14. Bhattarai, J., Akiyama, E., Habazaki, H., Kawashima, A., Asami K. and Hashimoto, K. 1998. Corrosion Science. 40: 19-42.

15. Bhattarai, J., Akiyama, E., Habazaki, H., Kawashima, A., Asami K. and Hashimoto, K. 1998. Corrosion Science. 40: 1897-1914.

16. Jha, H. and Bhattarai, J. 2008. Journal of Alloys \& Compounds. 456: 474-478.

17. Bhattarai, J., Akiyama, E., Habazaki, H., Kawashima, A., Asami K. and Hashimoto, K. 1998. Corrosion Science. 40: 757-779.

18. Bhattarai, J. 2006. Journal of Nepal Chemical Society. 21: 19-25.

19. Bhattarai, J. 2009. Scientific World. 7(7): 24-28.

20. Bhattarai, J. 2010. Transactions of Materials Research Society of Japan. 35(1): 1-6.

21. Bhattarai, J. 2010. Journal of Nepal Chemical Society. 26: 13-21.

22. Shrestha, P. and Bhattarai, J. 2010. Journal of Nepal Chemical Society. 25: 37-45.

23. Hashimoto, K. and K. Asami, K. 1979. Corrosion Science. 19, 251.

24. Naka, M., Hashimoto, K., Inoue, A. and Masumoto, T. 1979. Journal of Non-Crystalline Solids. 31: 347.

25. Moffat, T. P., Latanision, R. M. and Ruf, R. R. 1995. Electrochimica Acta. 40: 1723.

26. Basnet, M. and Bhattarai, J. 2010. Journal of Nepal Chemical Society. 25: 53-61.

27. Yoshioka, H., Habazaki, H., Kawashima, A., Asami, K. and Hashimoto, K. 1991. Electrochimica Acta. 36: 1227-1233.

28. Kim, J. H., Akiyama, E., Habazaki, H., Kawashima, A., Asami, K. and Hashimoto, K. 1993. Corrosion Science. 34: 1817-1827.

29. Park, P. Y., Akiyama, E., Habazaki, H., Kawashima, A., Asami, K. and Hashimoto, K. 1995. Corrosion Science. 37: 307-320.

30. El-Moneim, A. A, Akiyama, E., Habazaki, H., Kawashima, A., Asami, K. and Hashimoto, K. 1999. Corrosion-resistant Mn$\mathrm{Zr}-\mathrm{Cr}$ alloys in chloride-containing media. Materials Science and Engineering. A267: 285-293.

31. Pourbaix, M. 1974. Atlas of Electrochemical Equilibrium in Aqueous Solution, National Association of Corrosion Engineers, Huston, TX, pp. 223-229.

32. Pourbaix, M. 1974. Atlas of Electrochemical Equilibrium in Aqueous Solution, National Association of Corrosion Engineers, Huston, TX, pp. 256-271.

33. Pourbaix, M. 1974. Atlas of Electrochemical Equilibrium in Aqueous Solution, National Association of Corrosion Engineers, Huston, TX, pp. 280-285.

34. Aryal, B. R. and Bhattarai, J. 2010. Journal of Nepal Chemical Society. 25: 75-82. 